\title{
Distribution of the most common polymorphisms in TYMS gene in Slavic population of central Europe
}

\author{
A. PASTORAKOVA*, D. CHANDOGOVA, J. CHANDOGA, J. LUHA, D. BOHMER, J. MALOVA, T. BRAXATORISOVA, M. JUHOSOVA, S. REZNAKOVA, \\ R. PETROVIC \\ Comenius University in Bratislava, Faculty of Medicine, Institute of Medical Biology, Genetics and Clinical Genetics, Sasinkova 4, Bratislava 811 08, \\ Slovakia \\ ${ }^{*}$ Correspondence: andrea.pastorakova@fmed.uniba.sk
}

Received April 7, 2017/ Accepted July 19, 2017

\begin{abstract}
Thymidylate synthetase (TS) plays a critical role in the de novo synthesis of dTMP inside the cell. Therefore, TS is a suitable target for cytotoxic drugs such as fluoropyrimidines. Drug efficacy and toxicity depend on the intracellular level of TS, which is significantly influenced by the polymorphisms in the 5'UTR (TSER - rs45445694, TSER 3 G >C - rs2853542) and 3'UTR (1494del TTAAAG - rs151264360) of TYMS gene. Polymorphic variants of TYMS gene affect TS activity via gene expression and transcript stability. Patients who undergo fluoropyrimidine therapy may benefit from genetic testing prior to the administration of chemotherapy. At the 5 ' terminus of TYMS, there is a polymorphic region represented by a variable number of $28 \mathrm{bp}$ long tandem repeats (2-9 tandems) with the $\mathrm{G}$ or $\mathrm{C}$ nucleotide variant (SNP G>C). The 3'end of TYMS gene may decrease the stability of mRNA in the case of 6 base deletion (1494del6, D). In our study, we have focused on testing of TYMS gene polymorphisms, determination of TYMS variant frequencies in Western Slavic population and comparison of Slovak population with other populations.

We performed identification of 5'UTR (rs45445694 - TSER ${ }^{\star} 2$ or TSER ${ }^{\star} 3$; rs $2853542-\mathrm{TSER}^{\star} 3 \mathrm{G}>\mathrm{C}$; TSER ${ }^{\star 3}+$ ins 6 ) and 3’UTR (rs151264360/1494del6/D) polymorphic regions of TYMS gene among 96 volunteers by PCR-RFLP and fragment analysis. Slovak frequencies of selected polymorphisms were established as follows: the frequency of TSER ${ }^{\star}$, TSER 3 , TSER $^{\star} 3 \mathrm{G}>\mathrm{C}, 1494 \mathrm{del} 6 / \mathrm{D}$ and I to be $41 \%, 59 \%, 34 \%, 37.5 \%$ and $62.5 \%$ respectively. The high resolution of the capillary electrophoresis technique allowed among TSER ${ }^{\star} 3$ group identification of a subgroup of four individuals with rare 6bp insertion in $3 \mathrm{R}$ allele, id est $2.1 \%$ TSER ${ }^{\star} 3+$ ins 6 allele frequency. In our study, we have revealed individuals with rare $\mathrm{G}>\mathrm{C}$ substitution in the first $28 \mathrm{bp}$ tandem repeat of TSER ${ }^{\star}$ promoter enhancer region (rs183205964) as well, the overall frequency of this polymorphic allele in Slovak population was $2.1 \%$.

Our results proved that Slovak population is in Hardy-Weinberg equilibrium and proportion of TYMS polymorphisms is in accordance with other published data.
\end{abstract}

Key words: fluoropyrimidines, thymidylate synthetase, pharmacogenetics, polymorphism, Slovak

Fluoropyrimidine drugs such as 5-fluorouracil (5-FU) and the prodrugs represented by capecitabine and tegafur are extensively used in cancer therapy. The fluoropyrimidine treatment efficiency depends on the intracellular level of the enzyme thymidylate synthetase (TS). If TS is inhibited by fluoropyrimidines, the production of dTMP in the cell is blocked, which leads to the misincorporation of 5-FU metabolites into RNA and DNA, and finally to cell-cycle arrest and apoptosis [1]. Thymidylate synthetase protein is coded by TYMS gene consisting of 7 exons located on chromosome 18 (18p11.32). The therapy outcome and also toxicity are influenced by TS cellular content which depends on the interpatient genetic variability [2].

Expression and stability of thymidylate synthetase vary according to the polymorphisms in the variable number of 28-bp tandem repeats and SNP (single nucleotide polymorphism) in the 5'-untranslated region (UTR) and also depend on 6-bp insertion/deletion polymorphism in the 3'UTR of TYMS gene (Fig. 1). TYMS promoter enhancer region (TSER) contains the variable number of $28 \mathrm{bp}$ tandem repeats (CCGCGCCACTTGGCCTGCCTCCGTCCCG) which are repeated from 2 up to 9 times (rs45445694 for- 


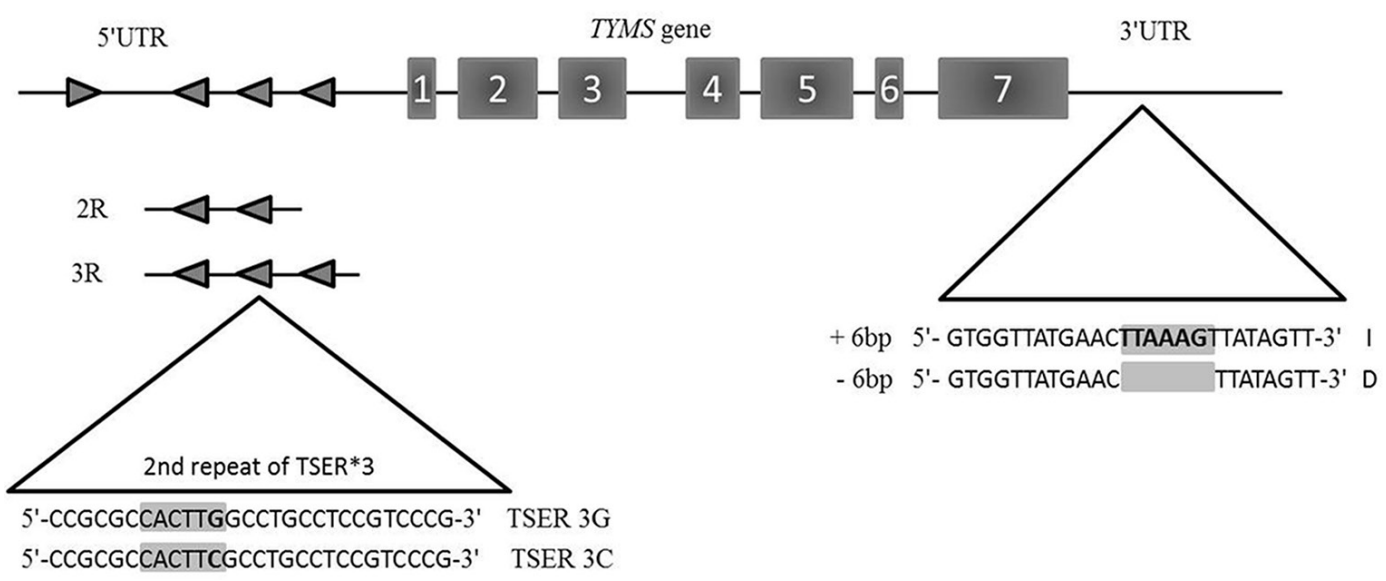

Figure 1. Structure of TYMS gene and 5'UTR and 3'UTR polymorphisms. TSER - Thymidylate Synthetase Enhancer Region, R - 28bp tandem repeat, I - I allele and D - D allele.

merly described as rs34743033), more prevalent as duplet $\left(2 \mathrm{R}, \mathrm{TSER}{ }^{\star}\right)$ or triplet $\left(3 \mathrm{R}, \mathrm{TSER}{ }^{\star} 3\right)$ [3]. Increased number of repeats raises TYMS RNA concentration and protein synthesis [3-6]. Every repeat contains E-box (enhancer box) binding site for upstream stimulatory factors (USF-1/USF2) functional only when guanine $(G)$ at the last position of CACTTG sequence is present. Both $2 \mathrm{R}$ and $3 \mathrm{R}$ wild-type alleles contain a cytosine in the last repeat which abolished the USF binding site in the repeat [7]. A clinical association has been found between reduced toxicity and drug efficacy in case of the $3 \mathrm{R} / 3 \mathrm{R}$ genotype, contrary patients with the $2 \mathrm{R} / 2 \mathrm{R}$ genotype showed an increased risk of toxicity, an increased response to fluoropyrimidine chemotherapy, and an increased survival time compared to individuals with the $2 \mathrm{R} / 3 \mathrm{R}$ or $3 \mathrm{R} / 3 \mathrm{R}$ genotype. The frequency of TSER ${ }^{*} 3(3 \mathrm{R})$ in the world is in the range from 50 to $60 \%$ except for Asian populations where the prevalence of TSER ${ }^{\star} 3$ is significantly higher (over 80\%) [3, 8, 9].

The SNP G>C substitution in the 12th nucleotide in the second repeat of TSER ${ }^{*} 3$ (rs2853542) alters TYMS expression by abolishing a transcription factor binding site $[7,10]$. Patients with TSER ${ }^{\star} 3 \mathrm{G}>\mathrm{C}\left(\mathrm{TSER}^{\star} 3 \mathrm{C}, 3 \mathrm{C}\right)$ polymorphism have a greater risk of toxicity due to the reduction in TYMS expression [10]. The TSER ${ }^{\star} 3$ patient might be stratified into high and low TYMS expression groups according to the presence of the $\mathrm{TSER}^{\star} 3 \mathrm{G}>\mathrm{C}$ polymorphism.

Decreased mRNA stability in vitro and lower gene expression in vivo was revealed by Mandola et al. [11] in association with the 3'UTR 6bp deletion allele located 447bp downstream of the TYMS transcription stop codon (rs151264360 formerly described as rs34489327 or rs16430; 1494del6, D) (Fig. 1). Frequency of variant with 6bp deletion in Caucasians is $26-29 \%$, $50 \%$ in Africans, and up to $76 \%$ in Asians $[11,12]$.

Other genetic and clinical factors may be also taken into account that may affect patient's risk for toxicity, survival time and therapy response.
The aim of this study was to analyse TYMS variants in Slovak population for the first time, to determine the frequency of polymorphisms in TYMS gene and to compare our findings with other populations. This study provides valuable information about the genetic variability of TYMS gene in Western Slavic population, hitherto missing.

\section{Materials and methods}

Samples of healthy unrelated volunteers were analysed by PCR, RFLP and fragment analysis (capillary electrophoresis) to estimate polymorphism frequencies in Slovak population. The analysed group consisted of 96 generally healthy individuals of Caucasian origin, randomly selected from the database of volunteers available at the Institute of Medical Biology, Genetics and Clinical Genetics, participants signed a written informed consent before participation in this study. Acquired data were checked for Hardy-Weinberg equilibrium and genetic linkage between variations.

DNA isolation. Blood samples for DNA extraction were collected in $3 \mathrm{ml}$ tubes containing potassium EDTA. Whole blood DNA was extracted from $200 \mathrm{ml}$ uncoagulated blood using Purification DNA Kit (DNA NucleoSpin Blood Kit; Macherey-Nagel, Düren, Germany).

Allele analysis. The 5'UTR VNTR (variable number of tandem repeats) region and 3'UTR region were amplified by PCR, the primers and PCR conditions used were previously described by Kawakami et al. [5] and by Ulrich et al. [12] were optimized for our laboratory settings. Primers for 5'UTR region (polymorphisms 2R/TSER ${ }^{\star} 2,3 \mathrm{R} / \mathrm{TSER}^{\star} 3$ - rs45445694; TSER $^{\star} 3+$ ins6) amplification primers and conditions as follow: 5'-[6FAM] GCGGAAGGGGTCCTGCCA-3' and 5'-TCCGAGCCGGCCACAGGCAT-3', PCR Master Mix (Thermo Fisher Scientific, Massachusetts, USA), PCR conditions: 5 min at $95{ }^{\circ} \mathrm{C}$; 30 cycles: $15 \mathrm{sec}$ at $95 \mathrm{C}, 30 \mathrm{sec}$ at $68^{\circ} \mathrm{C}, 30 \mathrm{sec}$ at $72^{\circ} \mathrm{C} ; 5$ min at $72{ }^{\circ} \mathrm{C}$. 
For 3'UTR region (1494del6/TYMSdel/D,I - rs151264360) amplification primers and condition as follow: 5'-[HEX] CAAATCTGAGGGAGCTGAGT-3'and 5'-CAGATAAGTGGCAGTACAGA-3, PCR Master Mix (Thermo Fisher Scientific, Massachusetts, USA), PCR conditions: $5 \mathrm{~min}$ at $95^{\circ} \mathrm{C}$; 30 cycles: $15 \mathrm{sec}$ at $95^{\circ} \mathrm{C}, 30 \mathrm{sec}$ at $60^{\circ} \mathrm{C}, 30 \mathrm{sec}$ at $72^{\circ} \mathrm{C}$; $5 \mathrm{~min}$ at $72^{\circ} \mathrm{C}$.

PCR products of 5'UTR and 3'UTR region were analysed with the ABI Prism 310 Genetic Analyzer (Applied Biosystems, USA) (Figure 2).

SNP analysis (PCR-RFLP). SNP of G or C in $2 \mathrm{R}$ and $3 \mathrm{R}$ allele ( $\mathrm{G}>\mathrm{C}$ substitution) [13]: VNTR PCR products were digested 16 hours at $37^{\circ} \mathrm{C}$ with HaeIII (New England Biolabs, Massachusetts, USA). Detection of the SNP was performed after electrophoresis (Origins 2100U, Elchrom Scientific, Switzerland) in Spreadex EL 300 Wide Mini S-2x13 or Spreadex EL 300 Wide Mini S-2x25 and staining with GelRed Nucleic Acid Gel Stain (Biotium, California, USA). Briefly, SNP detection: for 3G (3R-GGC) - fragments: 31bp - 28bp - 66bp - 10bp; 3C (3R-GCC): $31 b p-94 b p-10 b p ; 2 G C(w t$
2R allele): $31 b p-66 b p-10 b p ; 2 G G: 31 b p-28 b p-38 b p$ - 10bp; 2CG (2R-CG): 59bp - 38bp - 10bp; 2CC (2R-CC): 97bp - 10bp (Figure 3).

PCR-RFLP was used to confirm results of $3^{\prime}$ UTR region fragment analysis using PCR product digestion with DraI (New England Biolabs, Massachusetts, USA), D allele $-142 \mathrm{bp}$ fragment, I allele - 60bp and 88bp fragment (Figure 3) [12].

Statistic methods. Chi-square test was used to confirm or rule out whether the Slovak population is in accordance with Hardy-Weinberg equilibrium (Table 1,2).

Fisher's exact test of contingency tables was applied to detect significant differences in frequency of alleles in Slovak and other population. If the $\mathrm{P}$-value of appropriate test is $\mathrm{P}<0.05$; the corresponding distributions are significantly different at the 5\% significance level. In the tables, significantly different P-values are marked bold (Table 3).

Sample power test was used to analyse the strength of Fisher's exact test for significantly different results of allele distribution (Table 3).

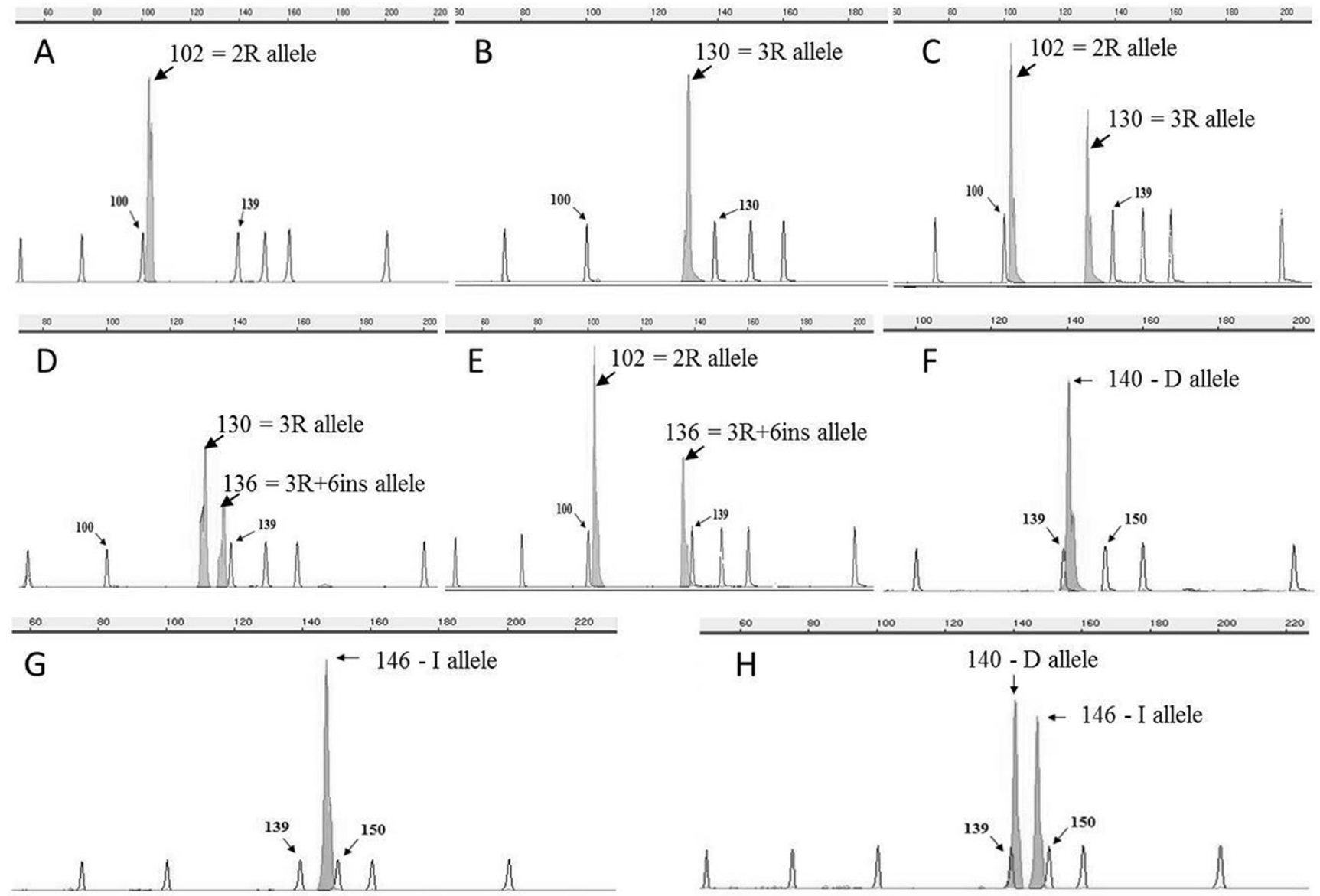

Figure 2. Fragment analysis of 5'UTR TSER region (2R, 3R, 3R+ins6) and 3'UTR region (D and I alleles) of TYMS gene. A) 2R/2R homozygote represented by fragment 102bp, B) $3 R / 3 R$ homozygote - 130bp fragment, C) $2 R / 3 R$ heterozygote $-102 \mathrm{bp} / 130 \mathrm{bp}, \mathrm{D}) 3 \mathrm{R} / 3 \mathrm{R}+\mathrm{ins} 6 \mathrm{heterozygote}-130 \mathrm{bp} / 136 \mathrm{bp}, \mathrm{E}$ ) $2 \mathrm{R} / 3 \mathrm{R}$ +ins6 heterozygote $-102 \mathrm{bp} / 136 \mathrm{bp}$. The nearest size standard peaks 100 and $139 \mathrm{bp} . \mathrm{F}) \mathrm{D} / \mathrm{D}$ homozygote represented by fragment $140 \mathrm{bp}, \mathrm{G}) \mathrm{I} / \mathrm{I}$ homozygote - 146bp fragment, H) D/I heterozygote - 140bp/146bp. The nearest size standard peaks 139 and $150 \mathrm{bp}$. 


\section{Results}

We have genotyped 96 Slovak DNA samples of healthy volunteers and determined frequencies of TYMS polymorphisms in Slovak population for the first time. Using fragment analysis of the 5'UTR VNTR TYMS region, we have identified five different genotypes and the following frequencies: TSER ${ }^{\star} 2$ / TSER ${ }^{\star} 2$ homozygotes represented by $20.8 \%$, TSER $* 3 / \mathrm{TSER}^{\star} 3$ homozygotes with $35.4 \%$ portion, $\mathrm{TSER}^{\star} 2 / \mathrm{TSER}^{\star} 3$ heterozygotes with $39.6 \%$ ratio, $\mathrm{TSER}^{\star} 3 / \mathrm{TSER}^{\star} 3+\mathrm{ins} 6$ with $3.1 \%$ and $\operatorname{TSER}^{\star} 2 / \mathrm{TSER}^{\star} 3+$ ins 6 with $1.1 \%$ (Table 1 ). The overall frequency of TSER ${ }^{\star} 3$ (with TSER ${ }^{\star} 3+$ ins6) prevalent allele was $59 \%$, the TSER ${ }^{\star} 2$ portion was $41 \%$ (Table 3 ). Within the TSER ${ }^{\star} 3$ allele, we have distinguished TSER ${ }^{\star} 3$ allele with $6 \mathrm{bp}$ insertion (TSER ${ }^{\star} 3+$ ins6) with $2.1 \%$ portion (Table 1 ). Based on the Chi-square test the distribution of the allelic variants
Table 1. Genotypes and allele frequencies of 5'UTR TSER region polymorphism (2R, 3R, 3R+ins6) and 3'UTR region polymorphism (D and I) in Slovak population.

\begin{tabular}{lcccc}
\hline Genotype & Number & $\begin{array}{c}\text { Frequency } \\
(\%)\end{array}$ & Allele & $\begin{array}{c}\text { Frequency } \\
(\%)\end{array}$ \\
\hline 2R/3R & 38 & 39.6 & $3 \mathrm{R}$ & 56.8 \\
3R/3R & 34 & 35.4 & $2 \mathrm{R}$ & 41.1 \\
2R/2R & 20 & 20.8 & 3R+ins6 & 2.1 \\
3R/3R+ins6 & 3 & 3.1 & & \\
2R/3R+ins6 & 1 & 1.1 & & \\
& & & & \\
D/I & 50 & 52.1 & $\mathrm{I}$ & 62.5 \\
I/I & 35 & 36.5 & $\mathrm{D}$ & 37.5 \\
D/D & 11 & 11.4 & & \\
\hline
\end{tabular}

Chi-square test confirmed the Hardy-Weinberg equilibrium in Slovak population (5'UTR TSER $\mathrm{P}=0.740$, 3'UTR polymorphisms $\mathrm{P}=0.553$ ).

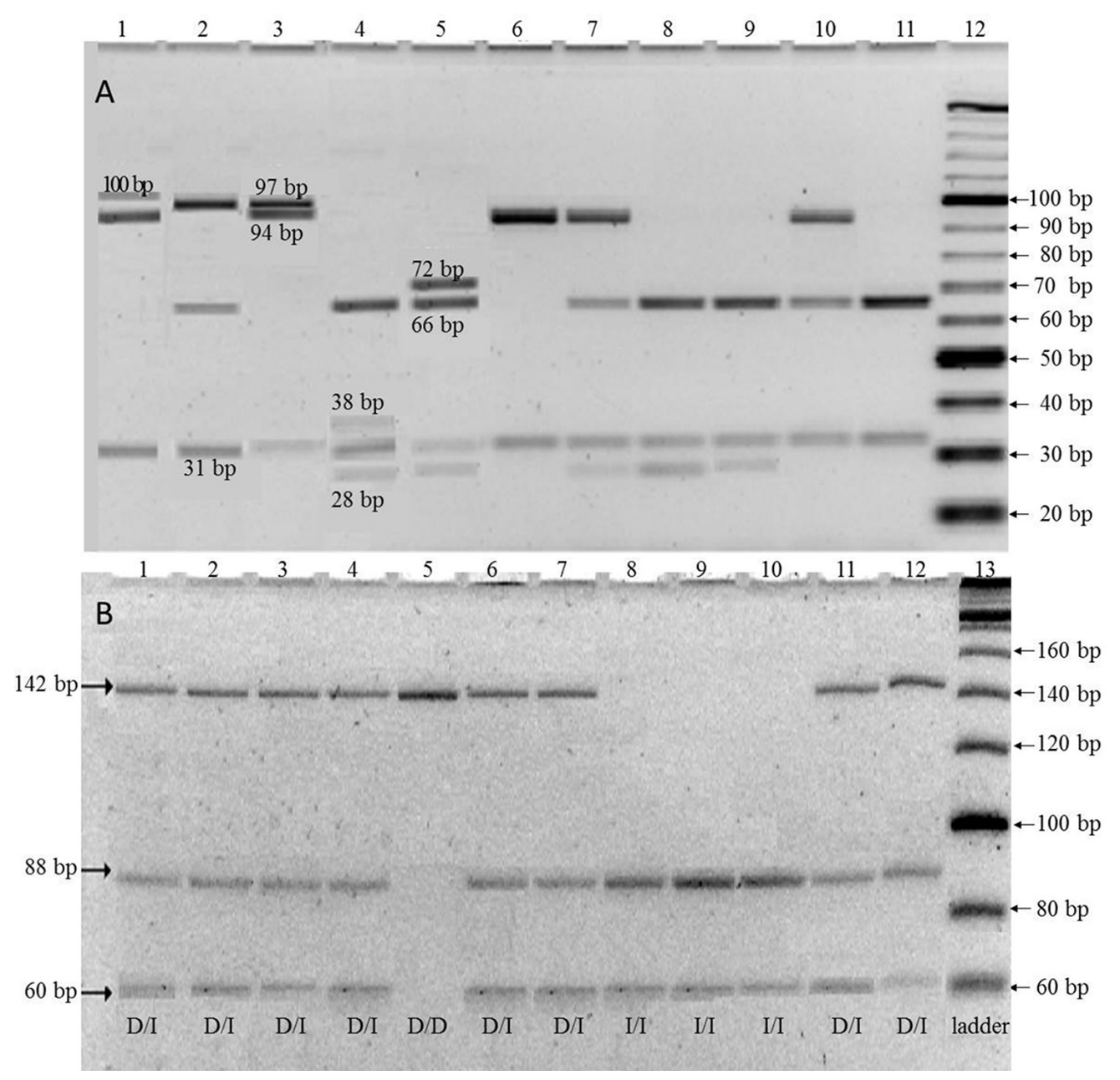

Figure 3. PCR-RFLP A) of 5'UTR region fragment analysis using HaeIII digestion of PCR products (sample, genotype, fragments). 1 - 3C/3C+ins6 $100 \mathrm{bp}$ and $94 \mathrm{bp}$ fragments; $2-2 \mathrm{CC} / 2 \mathrm{GC}-97 \mathrm{bp}$ and $66 \mathrm{bp}, 3-2 \mathrm{CC} / 3 \mathrm{C}-97 \mathrm{bp}$ and $94 \mathrm{bp}, 4-2 \mathrm{GG} / 2 \mathrm{GC}-38 \mathrm{bp}, 66 \mathrm{bp}$ and $28 \mathrm{bp}, 5-2 \mathrm{GC} / 3 \mathrm{G}+\mathrm{ins} 6-72 \mathrm{bp}$, 66bp and 28bp, $6-3 \mathrm{C} / 3 \mathrm{C}-94 \mathrm{bp} ; 7-3 \mathrm{C} / 3 \mathrm{G}-94 \mathrm{bp}, 66 \mathrm{bp}$ and $28 \mathrm{bp} ; 8-3 \mathrm{G} / 3 \mathrm{G}-66 \mathrm{bp}$ and $28 \mathrm{bp} ; 9-2 \mathrm{GC} / 3 \mathrm{G}-66 \mathrm{bp}$ and $28 \mathrm{bp} ; 10-2 \mathrm{GC} / 3 \mathrm{C}-94 \mathrm{bp}$ and 66bp; 11 - 2GC/2GC - 66bp, 12 - DNA ladder. B) of 3'UTR region fragment analysis using DraI digestion of PCR product. D allele -142bp fragment, I allele - 60bp and 88bp fragment. PCR-RFLP confirmed results of fragment analysis of all 96 samples. Sample genotypes: 1, 2, 3, 4, 6, 7, 11, 12 - D/I heterozygote; 5 - D/D homozygote; 8, 9, 10 - I/I homozygote; 13 - DNA ladder. 
Table 2. Distribution of SNP (G>C substitution) genotypes and alleles of TYMS in Slovak population.

\begin{tabular}{lcccc}
\hline Genotype & Number & $\begin{array}{c}\text { Frequency } \\
(\%)\end{array}$ & Allele & $\begin{array}{c}\text { Frequency } \\
(\%)\end{array}$ \\
\hline 2GC/3C & 23 & 24 & $2 \mathrm{GC}$ & 38.5 \\
$3 \mathrm{C} / 3 \mathrm{G}$ & 21 & 21.9 & $3 \mathrm{C}$ & 32.8 \\
$2 \mathrm{GC} / 2 \mathrm{GC}$ & 17 & 17.7 & $3 \mathrm{G}$ & 24.0 \\
$2 \mathrm{GC} / 3 \mathrm{G}$ & 13 & 13.5 & $2 \mathrm{CC}$ & 2.1 \\
$3 \mathrm{C} / 3 \mathrm{C}$ & 7 & 7.3 & $3 \mathrm{C}+$ ins 6 & 1.6 \\
$3 \mathrm{G} / 3 \mathrm{G}$ & 6 & 6.3 & $2 \mathrm{GG}$ & 0.5 \\
$3 \mathrm{C} / 3 \mathrm{C}+$ ins6 & 3 & 3.1 & $3 \mathrm{G}+$ ins6 & 0.5 \\
2CC/2GC & 2 & 2.1 & & \\
2CC/3C & 2 & 2.1 & & \\
2GC/2GG & 1 & 1 & & \\
2GC/3G+ins6 & 1 & 1 & & \\
\hline
\end{tabular}

Chi-square test confirmed the Hardy-Weinberg equilibrium in Slovak population $(\mathrm{P}=0.999)$.

of TYMS in Slovak population (Table 1) is in Hardy-Weinberg equilibrium. The detection of the TSER ${ }^{\star} 3+$ ins 6 allele was probably not within the detection limit in the studies with which we compared our population. Therefore, when comparing the frequencies of different populations, we have merged the frequency of TSER $* 3+$ ins 6 allele with TSER ${ }^{\star} 3$ allele frequency. The frequencies of investigated polymorphisms correlate with data previously reported for Caucasians. Based on the calculated P-value the significant difference was found in frequency of $2 \mathrm{R}$ and $3 \mathrm{R}$ polymorphic allele (rs45445694) between Chinese, Kenyan, Ghanaian populations comparing to Slovak population, while the proportion of TSER ${ }^{\star}$ and TSER $^{\star} 3$ was similar in the rest of the analysed populations (Macedonia, African-Americans, American and British Caucasians, Southwest Asian, and Spain) (Table 3). The sample power for comparative analysis of Slovak and: the population of Kenya (0.95), the population of Ghana (0.93) and Chinese population (0.999) is strong.

We have used PCR-RFLP analysis to confirm the distribution of genotypes and allele among Slovaks and to subdivide groups into detailed categories according to the content of $\mathrm{G}$ or $\mathrm{C}$ within the twelfth nucleotide of the $28 \mathrm{bp}$ repeats of TSER $^{\star} 2$, TSER $^{\star} 3$ or TSER $* 3+$ ins6 (Table 2). Frequency of wild-type TSER ${ }^{\star}$ allele (2GC) was $38.5 \%$, 3C allele (without $3 \mathrm{C}+$ ins6) $32.8 \%$, $3 \mathrm{G}$ allele (without $3 \mathrm{G}+$ ins6) $24 \%$; we have also come across rare alleles, such as the 2CC allele with $2.1 \%$ frequency, $3 \mathrm{C}+$ ins 6 allele with $1.6 \%$ portion, $2 \mathrm{GG}$ allele $0.5 \%$ and $3 \mathrm{G}+$ ins6 $0.5 \%$. Based on the Chi-square test, the distribution of TSER ${ }^{\star} 2(2 \mathrm{GC}, 2 \mathrm{CC}, 2 \mathrm{GG}), \mathrm{TSER}^{\star} 3 \mathrm{G}$, TSER $^{\star} 3 \mathrm{C}$ allelic variants of TYMS in Slovak population is in Hardy-Weinberg equilibrium (Table 2). In order to compare our population with other studies, we merged Slovak 2GC, $2 \mathrm{CC}$ and $2 \mathrm{GG}$ frequencies to TSER ${ }^{\star}$ frequency $(41 \%)$ as well as the $3 \mathrm{C}+$ ins 6 frequency with $3 \mathrm{C}$ frequency $(34 \%)$ and also the $3 \mathrm{G}+\mathrm{ins} 6$ frequency with $3 \mathrm{G}(25 \%)$. In addition to this, the detailed investigation of SNP G or C variants in TSER ${ }^{*}$ (rs2853542) revealed a significant difference between Slovaks and African-Americans, and between Slovak and Chinese populations as well (Table 3 ). The sample power for comparative analysis of Slovak and African Americans (0.96), as well as Chinese population (1), is strong.

In our work, the polymorphism rs151264360 in the 3'UTR region of TYMS (1494del6/TYMSdel/D, I) was analysed by fragment analysis and the results were confirmed using PCRRFLP with $62.5 \%$ presence of I allele and $37.5 \%$ of D allele. The proportion of genotypes was as follows: more than half (52.1\%) D/I heterozygotes, 36.5\% I/I homozygotes, $11.4 \%$ $\mathrm{D} / \mathrm{D}$ homozygotes (Table 1). Distribution of $\mathrm{D}$ and I alleles is in Hardy-Weinberg equilibrium in Slovak population. Statistically significant difference in frequency of distribution of D and I alleles was found comparing Slovak and Spanish populations (Table 3). The sample power of Fisher's exact test comparing the population of Slovakia with the population of Spain is moderately strong (0.726).

In our study, we have analysed the distribution of combined genotypes of 5'UTR TSER region polymorphism (2R, 3R) and 3'UTR region polymorphism (D and I) in 37 volunteers ( $\mathrm{Ta}-$ ble 4). We have found 8 genotype combinations from possible genotypes and following frequencies: most prevalent genotype $3 \mathrm{R} / 3 \mathrm{R}-\mathrm{I} / \mathrm{D}$ with $24.4 \%$; then $2 \mathrm{R} / 3 \mathrm{R}-\mathrm{I} / \mathrm{D} 21.6 \% ; 2 \mathrm{R} / 2 \mathrm{R}-\mathrm{I} / \mathrm{I}$, $2 \mathrm{R} / 2 \mathrm{R}-\mathrm{I} / \mathrm{D}$ and $2 \mathrm{R} / 3 \mathrm{R}-\mathrm{I} / \mathrm{I}$ equally $10.8 \%$; $3 \mathrm{R} / 3 \mathrm{R}-\mathrm{I} / \mathrm{I}$ and $3 \mathrm{R} / 3 \mathrm{R}-\mathrm{D} / \mathrm{D}$ equally $8.1 \%$; and $2 \mathrm{R} 3 \mathrm{R}-\mathrm{D} / \mathrm{D} 5.4 \%$. We did not identify individuals with the genotype $2 R / 2 R-D / D$.

\section{Discussion}

TYMS gene genotyping is a way that can potentially help predict patient response to fluoropyrimidines prior to the use of chemotherapy, thus leading to better-personalized treatment. We have completed the genotype study of TYMS gene in Slovak population that shows the distribution of TYMS variants among Slovaks. Our study is unique not only because of the analysis of VNTR of TYMS gene but also because of $\mathrm{G}$ and $\mathrm{C}$ determination within the twelfth nucleotide of the $28 \mathrm{bp}$ repeat in every tandem. According to our knowledge, such analysis has been not published for any Western Slavic population yet. The TYMS allele frequencies in Slovaks are comparable with other published Caucasian populations. The most prevalent allele in our study was TSER ${ }^{\star} 3$ (3R) with $59 \%$ frequency, less frequent allele was TSER ${ }^{\star} 2$ allele with $41 \%$ portion, and we have also detected the rare 6-bp insertion in the TSER ${ }^{\star} 3$ allele (TSER ${ }^{*} 3+$ ins 6$)$ in the frequency of $2.1 \%$. The TSER* $3+$ ins 6 variant was firstly described by Thomas et al. with the frequency of $0.4 \%$ in Caucasians and $1.3 \%$ in African-Americans [13]. The functional effect of the 6-bp insertion in 5'UTR of the $3 \mathrm{R}$ allele remains to be determined. There were attempts to determine Western Slavic population, but the data are not detailed. In the study of Goricar and colleagues [14], the frequencies of two groups of genotypes for Slovenians are mentioned. The frequency for the first 
Table 3. Differences in frequency of 2R and 3R alleles; 2R, 3G and 3C alleles; $D$ and I alleles in Slovak and other populations analysed by Fisher's exact test of contingency tables.

\begin{tabular}{|c|c|c|c|c|c|c|c|}
\hline \multirow{2}{*}{ Population } & \multicolumn{4}{|c|}{ Allele frequency (\%) } & \multirow{2}{*}{ P-value } & \multirow{2}{*}{$\begin{array}{l}\text { Sample } \\
\text { power }\end{array}$} & \multirow{2}{*}{ Reference } \\
\hline & $2 \mathrm{R}$ & $3 \mathrm{R}$ & $4 \mathrm{R}$ & $9 \mathrm{R}$ & & & \\
\hline Slovakia $(\mathrm{n}=192)$ & 41 & 59 & ND & ND & & & Current study \\
\hline Macedonia $(n=210)$ & 38 & 62 & ND & ND & 0.476 & $\mathrm{NC}$ & [16] \\
\hline Kenya $(n=196)$ & 44 & 49 & 7 & ND & 0.000 & 0.950 & {$[8]$} \\
\hline Ghana $(n=496)$ & 40 & 56 & 3 & 1 & 0.028 & 0.930 & [8] \\
\hline African-Americans $(\mathrm{n}=184)$ & 46 & 52 & 2 & ND & 0.062 & NC & [8] \\
\hline American Caucasians $(\mathrm{n}=208)$ & 46 & 54 & ND & ND & 0.364 & NC & {$[8]$} \\
\hline British Caucasians ( $\mathrm{n}=194)$ & 45 & 54 & 1 & ND & 0.295 & NC & {$[8]$} \\
\hline China $(n=192)$ & 18 & 82 & ND & ND & 0.000 & 0.999 & {$[17]$} \\
\hline Southwest Asian $(\mathrm{n}=190)$ & 38 & 62 & ND & ND & 0.532 & $\mathrm{NC}$ & {$[17]$} \\
\hline \multirow[t]{2}{*}{ Spain $(n=250)$} & 47 & 53 & ND & ND & 0.248 & NC & {$[34]$} \\
\hline & $2 \mathrm{R}$ & $3 \mathrm{G}$ & $3 \mathrm{C}$ & other & & & \\
\hline Slovakia $(n=192)$ & 41 & 25 & 34 & $\mathrm{ND}$ & & & Current study \\
\hline Macedonia $(\mathrm{n}=210)$ & 38 & 23 & 39 & ND & 0.570 & NC & [16] \\
\hline Spain $(n=240)$ & 47 & 23 & 30 & ND & 0.448 & NC & {$[34]$} \\
\hline White Ethnicity ( $\mathrm{n}=198)$ & 41 & 26 & 33 & ND & 0.909 & NC & {$[10]$} \\
\hline Hispanic $(\mathrm{n}=196)$ & 42 & 30 & 26 & 2 & 0.062 & $\mathrm{NC}$ & {$[10]$} \\
\hline African Americans $(\mathrm{n}=118)$ & 48 & 37 & 15 & ND & 0.001 & 0.960 & {$[10]$} \\
\hline \multirow[t]{2}{*}{ China $(n=160)$} & 19 & 51 & 30 & ND & 0.000 & 1 & {$[10]$} \\
\hline & $\mathrm{D}$ & & I & & & & \\
\hline Slovakia $(\mathrm{n}=192)$ & 37 & & 63 & & & & Current study \\
\hline Caucasians $(\mathrm{n}=190)$ & 29 & & 71 & & 0.131 & NC & [12] \\
\hline Northern Ireland $(\mathrm{n}=888)$ & 32 & & 68 & & 0.150 & NC & {$[35]$} \\
\hline Spain $(n=256)$ & 26 & & 74 & & 0.013 & 0.726 & {$[34]$} \\
\hline
\end{tabular}

Significantly different P-value is marked bold, $\mathrm{n}=$ number of alleles, $\mathrm{ND}=$ not detected, $\mathrm{NC}=$ not calculated.

group of TSER ${ }^{\star} 2 /$ TSER $^{\star} 2$ homozygotes is $17.9 \%$ and for the other group, consisting of individuals with TSER ${ }^{\star} 2 / \mathrm{TSER}^{\star} 3$ and TSER ${ }^{\star} 3 /$ TSER $^{\star} 3$ genotypes, it is $82.1 \%$. Jakubowska et al. [15] published an analysis of Polish population for the genotype groups: $22 \%$ of TSER ${ }^{\star} 2 / \mathrm{TSER}^{\star} 2$ homozygotes, $30 \%$ of TSER ${ }^{\star} 3 / \mathrm{TSER}^{\star} 3$ homozygotes and $48 \%$ of heterozygotes consisting of individuals with TSER ${ }^{\star} 2 / \mathrm{TSER}^{\star} 3$ or TSER ${ }^{\star} 2$ / $\mathrm{TSER}^{\star} 4$ genotypes. Macedonian population, one of the South Slavs, has been studied by Kapedanovska and colleagues [16]. The distribution of Macedonian genotypes is as described: $12 \%$ TSER $^{\star} 2 / \mathrm{TSER}^{\star} 2$ homozygotes, $30 \% \mathrm{TSER}^{\star} 2 / \mathrm{TSER}^{\star} 3 \mathrm{C}$, $20 \% \mathrm{TSER}^{\star} 2 / \mathrm{TSER}^{\star} 3 \mathrm{G}, 19 \% \mathrm{TSER}^{\star} 3 \mathrm{C} / \mathrm{TSER}^{\star} 3 \mathrm{C}, 10 \%$ TSER $* 3 \mathrm{C} / \mathrm{TSER}^{\star} 3 \mathrm{G}$.

In our group of volunteers, we have not found individuals with 4 or more $28 \mathrm{bp}$ tandem repeats. We have found differences in the distribution of TSER polymorphic alleles between Slovak population comparing the populations of Kenya, Ghana, and China. According to the opinion of Marsh and colleagues [17], polymorphism of TSER in humans may be a by-product of migration rather than allele evolution; environmental and/or other epigenetic factors can shift the allele frequencies in different regional dietary variations. In selective pressure of low intake of thymidine individuals with higher thymidylate synthase, due to the multiplication of TSER tandem repeat have selective advantage. Zhang and colleagues [18] demonstrated that besides humans, TSER is length polymorphic in many nonhuman primates while monomorphic in others. They suggested that the most recent common ancestor of hominoids and Old World monkeys probably possessed triple repeats. But now triple and double repeats, via deletion of one repeat, are two dominant types in hominoids and Old Word monkeys.

Table 4. Distribution of combined genotypes of 5'UTR TSER region polymorphism (2R, 3R) and 3'UTR region polymorphism (D and I) in Slovak population.

\begin{tabular}{lcc}
\hline Genotype (N=37) & Number & Frequency (\%) \\
\hline 2R/2R, I/I & 4 & 10.8 \\
2R/2R, I/D & 4 & 10.8 \\
2R/2R, D/D & 0 & 0 \\
2R/3R, I/I & 4 & 10.8 \\
2R/3R, I/D & 8 & 21.6 \\
2R/3R, D/D & 2 & 5.4 \\
3R/3R, I/I & 3 & 8.1 \\
3R/3R, I/D & 9 & 24.4 \\
3R/3R, D/D & 3 & 8.1 \\
\hline
\end{tabular}

$\mathrm{N}=$ number of genotypes 
There have been numerous attempts to associate TSER polymorphisms with clinical outcomes in cancer patients receiving fluoropyrimidine therapy, conclusions have been inconsistent. Several studies have revealed links between TSER genotype and the response to chemotherapy, and mention that TSER ${ }^{\star} /$ TSER $^{\star} 2$ genotype or patients with at least one TSER ${ }^{2}$ allele have a better response to fluorouracil as compared to patients with TSER $* 3 / \mathrm{TSER}^{*} 3$ genotype $[4,19-22]$. In vitro studies have shown up to four times more efficient translation from a construct with three repeats compared with two repeats $[3,23]$. In the study of in vivo analysis of colorectal cancer tissues, no relation between genotype and transcription has been revealed, but TSER genotype was associated with TS protein expression. Specifically, cancer tissues with the $3 R / 3 R$ genotype had a significantly higher TS protein expression level than did those with the $2 \mathrm{R} / 3 \mathrm{R}$ genotype. Cancer tissue with $2 \mathrm{R} / 2 \mathrm{R}$ genotype had the lowest TS protein expression [23].

De Bock and colleagues [7] have analysed thymidylate synthase activity in vivo in patients with colorectal cancer according to TSER polymorphism by measurement of $2^{\prime}$-deoxyuridine (dUrd) plasma level, a surrogate marker of TS inhibition. Plasma levels of dUrd were significantly different between genotypes, but in contrast to others, not to the absolute number of functional repeated elements (USF E-box) [7]. This study suggests that not the number of functional sequences, but their position within the promoter determines TYMS gene activity [7].

Up to date, there are no prescription and genotyping recommendations of TYMS gene prior therapy. Accurate information about the activity of thymidylate synthase depending on TSER genotype is missing as well. There are several studies trying to find out TSER genotype-specific guidelines for fluoropyrimidines dosing. Haller et al. [24] demonstrated regional differences in the tolerability profiles of fluoropyrimidines in the retrospective study. More treatment-related toxicity was reported in the US patients compared with the rest of the world for bolus fluorouracil/leucovorin and capecitabine in first-line metastatic colorectal cancer and adjuvant colon cancer. In the adjuvant setting, a range of fluoropyrimidine tolerability was observed, with East Asian patients having the lowest, and US patients the highest [24]. Soo and colleagues [25] sought to develop TSER specific guideline for capecitabine dosing. In their phase I study, they revealed a possibility to escalate the capecitabine dose of TSER 3R/3R advanced and/or metastatic cancer patients from lower the FDA-approved dose (from $1250 \mathrm{mg} / \mathrm{m}^{2}$ to $1500 \mathrm{mg} / \mathrm{m}^{2}$ ) [25].

In accordance with previous studies, the significant inverse association between the 5-FU toxicity and number of $28 \mathrm{bp}$ tandem repeats in 5'UTR region of TYMS gene was reported by some authors $[4,26,27]$. In the Saif's case report, they have described the first case of severe takotsubo cardiomyopathy related to DPD deficiency (heterozygous for the c.85T $>\mathrm{C} \mathrm{mu-}$ tation) and homozygous polymorphism of TYMS (TSER ${ }^{\star} 2 /$ $\mathrm{TSER}^{\star} 2,2 \mathrm{R} / 2 \mathrm{R}$ ) in a patient with colon cancer following 5-FU containing regimen [28]. Despite controversy in the literature, overall TSER ${ }^{\star} 2 / \mathrm{TSER}^{\star} 2$ finding predicts improved survival of patients receiving 5 -FU chemotherapy but also increases the risk for 5-FU toxicity. Wang and colleagues have also observed pancytopenia and severe gastrointestinal toxicities in Caucasian TSER ${ }^{\star} 2 /$ TSER $^{\star} 2$ homozygous patient with squamous cell rectal cancer after initiated 5-FU therapy in combination with mitomycin- $\mathrm{C}$ and radiation therapy followed after surgical excision [29]. The G>C substitution within the 12th nucleotide of the second repeat of TSER ${ }^{\star} 3$ (rs2853542) alters the TYMS expression due to abolished USF-1 binding site [10]. Morganti et al. demonstrated the reduction in TYMS expression in the case of $\mathrm{G}>\mathrm{C}$ substitution in the second repeat of TSER ${ }^{\star} 3$ (TSER ${ }^{\star} 3 \mathrm{C}$ ) comparing to TSER ${ }^{\star} 3 \mathrm{G}$ homozygotes and other genotypes in the colonic mucosa of 48 colorectal cancer patients [30]. The frequency of TSER ${ }^{\star} 3 \mathrm{C}$ varies among world population from $15 \%$ in African Americans up to $33 \%$ in whites [10]. In Slovak population, TSER ${ }^{\star} 3 \mathrm{C}$ allele frequency was $34 \%$ including TSER $* 3 \mathrm{C}+\mathrm{ins} 6$ allele with frequency $1.6 \%$. Marcuello and colleagues showed an improved overall response in metastatic colorectal cancer patients receiving 5-fluorouracil with the low expression genotypes (patients without any TSER ${ }^{*} 3 \mathrm{G}$ alleles) [31]. This SNP may further stratify TSER ${ }^{*} 3$ individuals into high and low TYMS expression groups.

Another identified SNP with reduced effect on TS activity was analysed by Meulendijks and colleagues. They studied the $\mathrm{G}>\mathrm{C}$ substitution in the first $28 \mathrm{bp}$ tandem repeat of $2 \mathrm{R}$ promoter-enhancer region of TYMS (rs183205964 known as the $2 \mathrm{RC}$ allele) among 1605 patients of this 28 patients (1.7\%) carried the 2RC (our tag 2CC) allele. They observed significantly more frequent early severe toxicity and toxicity-related hospitalization in risk-associated genotype carriers (2RG/2RC, $3 \mathrm{RC} / 2 \mathrm{RC}$ and $2 \mathrm{RC} / 2 \mathrm{RC}$ ). There was only one patient with the rare genotype $2 \mathrm{RC} / 2 \mathrm{RC}$ in the study, who had to be hospitalized twice and had severe febrile neutropenia, diarrhoea, and hand-foot syndrome [32]. The G>C substitution in the first $28 \mathrm{bp}$ tandem repeat of promoter enhancer region of TYMS was firstly described by Lincz and colleagues in 2007 [33]. In our study, we have identified 2 individuals with genotype $2 \mathrm{RC} / 2 \mathrm{RG}$ (our tag $2 \mathrm{CC} / 2 \mathrm{GC}$ ) and 2 with $2 \mathrm{RC} / \mathrm{TSER}^{*} 3 \mathrm{C}$ (our tag 2CC/3C), the overall frequency of the rs183205964 polymorphic allele in Slovak population was $2.1 \%$.

On the other hand, Mandola et al. have measured TS mRNA amount in liver metastasis of 43 patients with advanced metastatic colorectal carcinoma and determined genotype - mRNA level correlation according to D and I allele presence. They found that patients with $\mathrm{D} / \mathrm{D}$ genotype had decreased intratumoral TS mRNA to approximately $24 \%$ of TS mRNA amount of intratumoral TS mRNA in individuals with I/I genotype, while TS expression of D/I heterozygotes fell between two extremes with roughly $48 \%$ [11].

The knowledge of patient genotype prior fluoropyrimidine may help therapists to adequately set up treatment and prevent undesirable complications and life-threatening conditions in the future, despite the fact that clear predictive strategy has 
not been developed for clinical use yet. Other comprehensive haplotype studies involving analysis of all aforementioned polymorphisms in a relationship with therapy effectiveness and the toxicity risks are necessary to achieve the prescription and genotyping recommendations of TYMS gene prior to therapy.

Acknowledgements: This study was supported by the grant from MZSR 2007/39-FNSPBA-04. For the English correction to MSc. Linda Vasilova, Institute of Foreign Languages, Faculty of Medicine, Comenius University in Bratislava, Slovakia.

\section{References}

[1] LONGLEY DB, HARKIN DP, JOHNSTON PG. 5-fluorouracil: mechanisms of action and clinical strategies. Nat Rev Cancer 2003; 3: 330-338. https://doi.org/10.1038/nrc1074

[2] MEULENDIJKS D, ROZEMAN EA, CATS A, SIKORSKA $\mathrm{K}$, JOERGER $\mathrm{M}$ et al. Pharmacogenetic variants associated with outcome in patients with advanced gastric cancer treated with fluoropyrimidine and platinum-based triplet combinations: a pooled analysis of three prospective studies. Pharmacogenomics J 2016. https://doi.org/10.1038/ tpj.2016.81

[3] HORIE N, AIBA H, OGURO K, HOJO H, TAKEISHI K. Functional analysis and DNA polymorphism of the tandemly repeated sequences in the 5 -terminal regulatory region of the human gene for thymidylate synthase. Cell Struct Funct 1995; 20: 191-197. https://doi.org/10.1247/csf.20.191

[4] PULLARKAT ST, STOEHLMACHER J, GHADERI V, XIONG YP, INGLES SA et al. Thymidylate synthase gene polymorphism determines response and toxicity of 5-FU chemotherapy. Pharmacogenomics J 2001; 1: 65-70. https:// doi.org/10.1038/sj.tpj.6500012

[5] KAWAKAMI K, OMURA K, KANEHIRA E, WATANABE Y. Polymorphic tandem repeats in the thymidylate synthase gene is associated with its protein expression in human gastrointestinal cancers. Anticancer Res 1999; 19: 3249-3252.

[6] ULRICH CM, BIGLER J, BOSTICK R, FOSDICK L, POTTER JD. Thymidylate synthase promoter polymorphism, interaction with folate intake, and risk of colorectal adenomas. Cancer Res 2002; 62: 3361-3364.

[7] DE BOCK CE, GARG MB, SCOTT N, SAKOFF JA, SCORGIE FE et al. Association of thymidylate synthase enhancer region polymorphisms with thymidylate synthase activity in vivo. Pharmacogenomics J 2011; 11: 307-314. https://doi. org/10.1038/tpj.2010.43

[8] MARSH S, AMEYAW MM, GITHANG'A J, INDALO A, OFORI-ADJEI D et al. Novel thymidylate synthase enhancer region alleles in African populations. Hum Mutat 2000; 16: 528. https://doi.org/10.1002/1098-1004(200012)16:6<528::AIDHUMU11>3.0.CO;2-W

[9] LUO HR, LU XM, YAO YG, HORIE N, TAKEISHI K et al. Length polymorphism of thymidylate synthase regulatory region in Chinese populations and evolution of the novel alleles. Biochem Genet 2002; 40: 41-51. https://doi. org/10.1023/A:1014589105977
[10] MANDOLA MV, STOEHLMACHER J, MULLER-WEEKS S, CESARONE G, YU MC et al. A novel single nucleotide polymorphism within the 5 ' tandem repeat polymorphism of the thymidylate synthase gene abolishes USF-1 binding and alters transcriptional activity. Cancer Res 2003; 63: 2898-2904.

[11] MANDOLA MV, STOEHLMACHER J, ZHANG W, GROSHEN S, YU MC et al. A 6 bp polymorphism in the thymidylate synthase gene causes message instability and is associated with decreased intratumoral TS mRNA levels. Pharmacogenetics 2004; 14: 319-327. https://doi. org/10.1097/00008571-200405000-00007

[12] ULRICH CM, BIGLER J, VELICER CM, GREENE EA, FARIN FM et al. Searching expressed sequence tag databases: discovery and confirmation of a common polymorphism in the thymidylate synthase gene. Cancer Epidemiol Biomarkers Prev 2000; 9: 1381-1385.

[13] THOMAS F, HOSKINS JM, DVORAK A, TAN BR, MCLEOD HL. Detection of the G>C SNP and rare mutations in the 28-bp repeat of TYMS using gel-based capillary electrophoresis. Pharmacogenomics 2010; 11: 1751-1756. https://doi. org/10.2217/pgs. 10.170

[14] GORICAR K, ERCULJ N, FAGANEL KOTNIK B, DEBELJAK $\mathrm{M}$, HOVNIK $\mathrm{T}$ et al. The association of folate pathway and DNA repair polymorphisms with susceptibility to childhood acute lymphoblastic leukemia. Gene 2015; 562: 203-209. https://doi.org/10.1016/j.gene.2015.02.077

[15] JAKUBOWSKA A, GRONWALD J, MENKISZAK J, GORSKI B, HUZARSKI T et al. BRCA1-associated breast and ovarian cancer risks in Poland: no association with commonly studied polymorphisms. Breast Cancer Res Treat 2010; 119: 201-211. https://doi.org/10.1007/s10549-009-0390-5

[16] KAPEDANOVSKA NESTOROVSKA A, JAKOVSKI K, NAUMOVSKA Z, HILJADNIKOVA BAJRO M, STERJEV $\mathrm{Z}$ et al. Distribution of the most Common Genetic Variants Associated with a Variable Drug Response in the Population of the Republic of Macedonia. Balkan J Med Genet 2015; 17: 5-14. https://doi.org/10.2478/bjmg-2014-0069

[17] MARSH S, COLLIE-DUGUID ES, LI T, LIU X, MCLEOD HL. Ethnic variation in the thymidylate synthase enhancer region polymorphism among Caucasian and Asian populations. Genomics 1999; 58: 310-312. https://doi.org/10.1006/ geno.1999.5833

[18] ZHANG YW, LUO HR, RYDER OA, ZHANG YP. Evolution of the tandem repeats in thymidylate synthase enhancer region (TSER) in primates. Gene 2004; 338:47-54. https://doi. org/10.1016/j.gene.2004.05.018

[19] IACOPETTA B1, GRIEU F, JOSEPH D, ELSALEH H. A polymorphism in the enhancer region of the thymidylate synthase promoter influences the survival of colorectal cancer patients treated with 5-fluorouracil. Br J Cancer 2001; 85: 827-830. https://doi.org/10.1054/bjoc.2001.2007

[20] KRAJINOVIC M, COSTEA I, CHIASSON S. Polymorphism of the thymidylate synthase gene and outcome of acute lymphoblastic leukaemia. Lancet 2002; 359: 1033-1034.

[21] VILLAFRANCA E, OKRUZHNOV Y, DOMINGUEZ MA, GARCÍA-FONCILLAS J, AZINOVIC I et al. Polymorphisms of the repeated sequences in the enhancer region of the 
thymidylate synthase gene promoter may predict downstaging after preoperative chemoradiation in rectal cancer. J Clin Oncol 2001; 19: 1779-1786. https://doi.org/10.1200/ LCO.2001.19.6.1779

[22] JOERGER M, HUITEMA AD, BOOT H, CATS A, DOODEMAN VD et al. Germline TYMS genotype is highly predictive in patients with metastatic gastrointestinal malignancies receiving capecitabine-based chemotherapy. Cancer Chemother Pharmacol 2015; 75: 763-772. https://doi.org/10.1007/ $\underline{\text { s00280-015-2698-7 }}$

[23] KAWAKAMI K, SALONGA D, PARK JM, DANENBERG $\mathrm{KD}$, UETAKE $\mathrm{H}$ et al. Different lengths of a polymorphic repeat sequence in the thymidylate synthase gene affect translational efficiency but not its gene expression. Clin Cancer Res 2001; 7: 4096-4101.

[24] HALLER DG, CASSIDY J, CLARKE SJ, CUNNINGHAM D, VAN CUTSEM E et al. Potential regional differences for the tolerability profiles of fluoropyrimidines. J Clin Oncol 2008; 26: 2118-2123. https://doi.org/10.1200/JCO.2007.15.2090

[25] SOO RA, SYN N, LEE SC, WANG L, LIM XY et al. Pharmacogenetics-Guided Phase I Study of Capecitabine on an Intermittent Schedule in Patients with Advanced or Metastatic Solid Tumours. Sci Rep 2016; 6: 27826. https://doi.org/10.1038/ srep27826

[26] LECOMTE T, FERRAZ JM, ZINZINDOHOUE F, LORIOT MA, TREGOUET DA et al. Thymidylate synthase gene polymorphism predicts toxicity in colorectal cancer patients receiving 5-fluorouracil-based chemotherapy. Clin Cancer Res 2004; 10: 5880-5888. https://doi.org/10.1158/1078-0432. CCR-04-0169

[27] ROSMARIN D, PALLES C, CHURCH D, DOMINGO E, JONES A et al. Genetic markers of toxicity from capecitabine and other fluorouracil-based regimens: investigation in the QUASAR2 study, systematic review, and meta-analysis. J Clin Oncol 2014; 32: 1031-1039. https://doi.org/10.1200/ JCO.2013.51.1857

[28] SAIF MW, SMITH M, MALONEY A. The First Case of Severe Takotsubo Cardiomyopathy Associated with 5-Fluorouracil in a Patient with Abnormalities of Both Dihydropyrimidine Dehydrogenase (DPYD) and Thymidylate Synthase (TYMS)
Genes. Cureus 2016; 8: e783. https://doi.org/10.7759/cu$\underline{\text { reus.783 }}$

[29] WANG B, WALSH SJ, SAIF MW. Pancytopenia and Severe Gastrointestinal Toxicities Associated with 5-Fluorouracil in a Patient with Thymidylate Synthase (TYMS) Polymorphism. Cureus 2016; 8: e798. https://doi.org/10.7759/cureus.798

[30] MORGANTI M, CIANTELLI M, GIGLIONI B, PUTIGNANO AL, NOBILI S et al. Relationships between promoter polymorphisms in the thymidylate synthase gene and mRNA levels in colorectal cancers. Eur J Cancer 2005; 41: 2176-83. https://doi.org/10.1016/j.ejca.2005.06.016

[31] MARCUELLO E, ALTES A, DEL RIO E, CESAR A, MENOYO A et al. Single nucleotide polymorphism in the 5 ' tandem repeat sequences of thymidylate synthase gene predicts for response to fluorouracil-based chemotherapy in advanced colorectal cancer patients. Int J Cancer 2004; 112: 733-737. https://doi. org/10.1002/ijc.20487

[32] MEULENDIJKS D, JACOBS BA, ALIEV A, PLUIM D, VAN WERKHOVEN $E$ et al. Increased risk of severe fluoropyrimidine-associated toxicity in patients carrying a $\mathrm{G}$ to $\mathrm{C}$ substitution in the first 28-bp tandem repeat of the thymidylate synthase $2 \mathrm{R}$ allele. Int J Cancer 2016; 138: 245-253. https:// doi.org/10.1002/ijc.29694

[33] LINCZ LF, SCORGIE FE, GARG MB, ACKLAND SP. Identification of a novel single nucleotide polymorphism in the first tandem repeat sequence of the thymidylate synthase $2 \mathrm{R}$ allele. Int J Cancer 2007; 120: 1930-1934. https://doi.org/10.1002/ ijc. 22568

[34] DOTOR E, CUATRECASES M, MARTÍNEZ-INIESTA M, NAVARRO M, VILARDELL $F$ et al. Tumor thymidylate synthase 1494del6 genotype as a prognostic factor in colorectal cancer patients receiving fluorouracil-based adjuvant treatment. J Clin Oncol 2006; 24: 1603-1611. https://doi. org/10.1200/JCO.2005.03.5253

[35] KEALEY C, BROWN KS, WOODSIDE JV, YOUNG I, MURRAY L et al. A common insertion/deletion polymorphism of the thymidylate synthase (TYMS) gene is a determinant of red blood cell folate and homocysteine concentrations. Hum Genet 2005; 116: 347-353. https://doi.org/10.1007/s00439004-1243-2 